\title{
Antibodies Targeting Human Endothelin-1 Receptors Reveal Different Conformational States in Cancer Cells
}

\author{
A. HERBET ${ }^{1}$, N. COSTA ${ }^{1}$, N. LEVENTOUX ${ }^{2,3}$, A. MABONDZO ${ }^{1}$, J.-Y. COURAUD ${ }^{1}$, \\ A. BORRULL ${ }^{1}$, J.-P. HUGNOT ${ }^{2,3}$, D. BOQUET ${ }^{1}$
}

${ }^{1}$ Service de Pharmacologie et Immunoanalyse (SPI), Laboratoire d'Etude du Métabolisme des Médicaments (LEMM), CEA, Université Paris Saclay, Gif-sur-Yvette, France, ${ }^{2}$ INSERM U1051, Institut des Neurosciences de Montpellier, Hôpital St Eloi, Montpellier, France, ${ }^{3}$ Université Montpellier 2, Montpellier, France

Received December 25, 2017

Accepted April 20, 2018

\section{Summary}

The endothelin axis (endothelins and their receptors) is strongly involved in physiological and pathological processes. ET-1 plays a crucial role in particular in tumor diseases. Endothelin-1 receptors $\left(\mathrm{ET}_{\mathrm{A}}\right.$ and $\left.\mathrm{ET}_{\mathrm{B}}\right)$ are deregulated and overexpressed in several tumors such as melanoma and glioma. We studied the binding of 24 monoclonal antibodies directed against human $\mathrm{ET}_{\mathrm{B}}$ receptors $\left(\mathrm{hET}_{\mathrm{B}}\right.$ ) to different melanoma cell lines. Few of these mAbs bound to all the melanoma cell lines. One of them, rendomab $\mathrm{B} 49$, bound to $\mathrm{ET}_{\mathrm{B}}$ receptors expressed at the surface of human glioma stem cells. More recently, we produced new antibodies directed against human $\mathrm{ET}_{\mathrm{A}}$ receptor $\left(\mathrm{hET}_{\mathrm{A}}\right)$. Several antibodies have been isolated and have been screened on different tumoral cells lines. As for the mAbs directed against the $\mathrm{hET}_{\mathrm{B}}$ receptor only some of new antibodies directed against $\mathrm{ET}_{\mathrm{A}}$ receptor are capable to bind the human tumoral cell lines. Rendomab $A 63$ directed against $\mathrm{hET}_{\mathrm{A}}$ is one of them. We report the specificity and binding properties of these mAbs and consider their potential use in diagnosis by an in vivo imaging approach.

\section{Key words}

Monoclonal antibodies • Endothelin-1 • Endothelin B receptor • Endothelin A receptor

\section{Corresponding author}

D. Boquet, Service de Pharmacologie et Immunoanalyse (SPI), Laboratoire d'Etude du Métabolisme des Médicaments (LEMM), CEA, Université Paris Saclay, F-91191 Gif-sur-Yvette cedex, France. E-mail: didier.boquet@cea.fr

\section{Introduction}

G-protein-coupled receptors (GPCRs), one of the largest and most widely represented therapeutic classes on the market. The cell signaling pathway of GPCRs is very complex. They operated as biological connectors that trigger multiple cell signaling events.

The functional selectivity of GPCRs, opens up promising for the identification and development of better performing drugs through selective activation of pathways relevant to the desired therapeutic response, while avoiding induction of pathways responsible for adverse effects.

Our laboratory has extensive know-how for the production of monoclonal antibodies (mAbs) targeting seven-transmembrane receptors (RCPGs) and seeks to develop innovative diagnostic or therapeutic medicines in key therapeutic indications. In this context, we developed specific antibodies targeting ET-1 receptors (ET1R) that could be promising for the treatment of diseases involving dysfunction of the endothelin axis. Since their discovery, endothelins and their receptors (i.e. the endothelin axis) have been implicated in a large variety of diseases (Barton and Yanagisawa 2008, Davenport et al. 2016). Endothelin-1 receptors $\left(\mathrm{ET}_{\mathrm{B}}\right.$ and $\left.\mathrm{ET}_{\mathrm{A}}\right)$ are involved in the two most prevalent diseases in humans, i.e. cardiovascular disorders and cancers. Several recent publications underline the importance of the endothelin-1 (ET-1) in tumor progression in certain cancers (for a review Rosanò et al. 2013). So, several drugs have been 
developed to target and inhibit the endothelin axis in different diseases, such as bosentan (Clozel et al. 1993) for the treatment of pulmonary artery hypertension or atrasentan (Opgenorth et al. 1996) in some cancers and diabetic nephropathy (Egido et al. 2017). We have previously detailed the properties of rendomab B1 (RB1) and B4 (RB4), which are antibodies directed against human subtype $\mathrm{B}$ endothelin receptor $\left(\mathrm{ET}_{\mathrm{B}}\right)$ obtained through genetic immunization (Allard et al. 2013, Borrull et al. 2016). Surprisingly, $\mathrm{RB} 1$ was unable to bind $\mathrm{ET}_{\mathrm{B}}$ at the surface of melanoma cell lines, in contrast to RB4. Here, we describe the binding profiles on melanoma cells of $24 \mathrm{mAbs}$ directed against human $\mathrm{ET}_{\mathrm{B}}$ receptors $\left(\mathrm{hET}_{\mathrm{B}}\right)$, obtained during the same immunization campaign that $\mathrm{RB} 1$ and RB4, and more precisely the patented rendomab B49 (RB49) which displays interesting properties for therapeutic applications in diseases overexpressing the $\mathrm{B}$ receptor as melanoma or glioblastoma. We also describe a new monoclonal antibody directed against human $\mathrm{ET}_{\mathrm{A}}\left(\mathrm{hET}_{\mathrm{A}}\right)$ receptor: the rendomab $\mathrm{A} 63$ (RA63) produced in the same way as rendomab B49. Its potential use as a diagnostic imaging tracer has been established in a glioblastoma preclinical animal model.

\section{Methods}

Cell culture, flow cytometry analysis, binding and competition experiments

Chinese hamster ovary (CHO) cells expressing $\mathrm{CHO}_{\mathrm{B}}, \mathrm{CHO}_{\mathrm{B}}, \mathrm{ET}_{\mathrm{A}}$ and melanoma cells lines were cultured as previously described (Borrull et al. 2016). Glioblastoma stem cells (GSC) were provided by Dr. J.P. Hugnot, INSERM U1051 (Guichet et al. 2014). Flow cytometry experiments were performed using a previously described protocol (Borrull et al. 2016). Briefly, to determine the affinity of RB49 and RA63, increasing concentrations of monoclonal antibody were incubated with $\mathrm{CHO}-\mathrm{ET}_{\mathrm{B}}$ or $\mathrm{CHO}-\mathrm{ET}_{\mathrm{A}}$ cells for $2 \mathrm{~h}$ at $4{ }^{\circ} \mathrm{C}$. RB49 and RA63 binding was revealed using Alexa-Fluor 488 conjugated AffiniPure goat anti-mouse IgG (H+L) (goat anti-mouse IgG, Invitrogen-ref

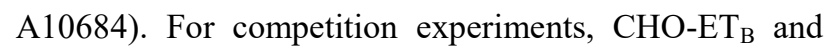
$\mathrm{CHO}_{\mathrm{A}} \mathrm{ET}_{\mathrm{A}}$ cells were incubated simultaneously with $100 \mathrm{nM} \mathrm{ET}-1$ at $4{ }^{\circ} \mathrm{C}$ for $30 \mathrm{~min}$ and then incubated with increasing concentrations of RB49 or RA63 for $2 \mathrm{~h}$ at $4{ }^{\circ} \mathrm{C}$. Mean fluorescence intensity (MFI) of samples was then given by cytometer software. The MFI results were analyzed and curves were fitted using GraphPad Prism with the adequate dose-response equation and IC $50 \pm 0.1$ $\mathrm{SD}$ values were determined.

\section{Epitope mapping}

The entire extracellular amino acid sequence of human $\mathrm{ET}_{\mathrm{B}}$ was synthesized on a cellulose membrane using the previously described SPOT technique (Allard et al. 2013). It displayed overlapping 12-mer peptides, frameshifted by one residue. Briefly, rendomab-B49 epitope mapping was performed by incubating the membrane with a saturation buffer $(2.5 \% \mathrm{w} / \mathrm{v}$ of dry milk for $30 \mathrm{~min}$ at RT). RB49 was added to a final concentration of $10 \mu \mathrm{g} / \mathrm{ml}$ and the mixture was left overnight at $4{ }^{\circ} \mathrm{C}$. After 3 washes in TBST buffer, hybridization was revealed using an anti-mouse $\mathrm{IgG}$ coupled with peroxidase diluted 1/5000 (SantaCruz \#SC-2005) and incubated for $45 \mathrm{~min}$ at RT. After 3 washes in TBST buffer, RB49 binding was revealed using Pierce ECL plus Western blotting substrate (Fischer Scientific, ref. \#32132).

\section{Confocal analysis}

Confocal microscopy analysis was performed on high-grade glioma stem cells (GSC) provided by Dr. J.P. Hugnot. Cells were seeded on glass coverslips at a density of 100,000 cells per $\mathrm{cm}^{2}$. GSC were incubated for $12 \mathrm{~h}$ at $4{ }^{\circ} \mathrm{C}$ with $30 \mathrm{nM}$ of RA63 or $30 \mathrm{nM}$ of RB49. After 3 washes in PBS, for antibody labeling, the secondary antibody, diluted at $1 / 400$, coupled with AF488 (Invitrogen-ref A10684), was added to the cells for $2 \mathrm{~h}$ at $4{ }^{\circ} \mathrm{C}$. After 3 washes in PBS, the cells were mounted in aqueous medium Aquatex ${ }^{\circledR}$ (supplier VWR 1085620050 ) on slides, to be observed under the confocal microscope (Zeiss-LSM 510 or Nikon TE200), at $40 \mathrm{x}$ magnification.

\section{In vivo experiments}

Eight-week-old female nude NMRI mice (Janvier) were kept in a specific pathogen-free animal facility. All animal experiments complied with French animal experimentation regulations and ethical principles.

Intracranial transplantation of GLI-7 cells $\left(5 \times 10^{5}\right.$ in $\left.2 \mu \mathrm{l}\right)$ was performed by injection into the striatum (1 $\mathrm{mm}$ anterior, $2 \mathrm{~mm}$ lateral from bregma, and $2.5 \mathrm{~mm}$ depth from dura) of nude mice under ketamine/xylazine $(100 \mathrm{mg} / \mathrm{kg} / 10 \mathrm{mg} / \mathrm{kg}) \quad$ anesthesia with the authorization of the local ethics committee. A $10 \mu \mathrm{l}$ Hamilton syringe was used with a flow rate of $1 \mu \mathrm{l} / \mathrm{min}$. All transplantations were performed under anesthesia and every effort was made to minimize the number of animals used and their suffering. After 3 months post-grafting, mice were intraperitoneally co-injected with RA63 conjugated with the fluorochrome 
Alexa Fluor 680 (RA63-AF680) and the negative isotype control conjugated with Alexa Fluor 750 (NC-AF750). At 10 days post-injection, mice were imaged under isofluorane ( $3 \%$ ) using a quantitative tomography in vivo imaging system (FMT 1500; Perkin Elmer), and were then euthanatized by intraperitoneal injection under ketamine/xylazine $(180 \mathrm{mg} / \mathrm{kg} / 20 \mathrm{mg} / \mathrm{kg})$ anesthesia. Brains were collected and imaged using the FMT 1500.

\section{Results}

Differential recognition of antibodies directed against $h E T_{B}$ receptor expressed by melanoma cell lines

We evaluated by flow cytometry the binding of our 24 antibodies against $\mathrm{hET}_{\mathrm{B}} \mathrm{R}$ to three human melanoma cell lines (UACC-257, WM-266-4 and SLM8) and to the $\mathrm{CHO}$ cell line stably transfected with $\mathrm{hET}_{\mathrm{B}}$
$\left(\mathrm{CHO}-\mathrm{ET}_{\mathrm{B}}\right)$. A saturation binding curve was considered as a positive result $(+)$ and lack of saturation as a negative result (-). The results obtained are presented in the Table 1. As expected, all the antibodies bound to $\mathrm{CHO}_{\mathrm{B}} \mathrm{ET}_{\mathrm{B}}$ because their hybridomas were selected according this criterion. More surprisingly, we observed variability in antibody binding as a function of the melanoma cell lines. We classified the antibodies into six groups. The $9 \mathrm{mAbs}$ of group I, including RB4 and rendomab B49 (RB49), bound to all cell lines. Conversely, the $5 \mathrm{mAbs}$ of group II, including RB1, only bound to the CHO-ET $\mathrm{B}$ cell line. The $3 \mathrm{mAbs}$ of group III bound to all cell lines except SLM8. The 2 mAbs of group IV, bound to all cell lines except WM-266-4. The $3 \mathrm{mAbs}$ of group $\mathrm{V}$ only bound to $\mathrm{CHO}^{-\mathrm{ET}_{\mathrm{B}}}$ and UACC-257, and the $2 \mathrm{mAbs}$ of group VI bound only to $\mathrm{CHO}_{\mathrm{B}} \mathrm{ET}_{\mathrm{B}}$ and SLM8.

Table 1. Positive or negative binding of rendomab B antibodies to different cell lines.

\begin{tabular}{lcccc}
\hline Groups (no. of mAbs)/cell lines & CHO-ET & UACC-257 & WM-266-4 & SLM8 \\
\hline Group I $(9 m A b s-R B 4-R B 49)$ & + & + & + & + \\
Group II $(5 \mathrm{mAbs}-\mathrm{RB} 1)$ & + & + & - & - \\
Group III $(3 \mathrm{mAbs})$ & + & + & - & + \\
Group IV $(2 \mathrm{mAbs})$ & + & + & - & - \\
Group V $(3 \mathrm{mAbs})$ & + & - & - & + \\
Group VI $(2 \mathrm{mAbs})$ & + & & + \\
\hline
\end{tabular}

Binding of rendomab $B 49$ and rendomab A63 to their respective endothelin receptors are not suppressed in presence of ET-1

The binding curve of RB49, determined by flow cytometry, clearly shows that RB49 binding is not modified in the presence of excess ET-1 (100 nM) (Fig. 1A), as previously observed for RB4 (Borrull et al. 2016). The calculated $\mathrm{K}_{\mathrm{D}}$ values are similar: $1.6 \pm 0.01 \mathrm{nM}$ for RB49 and $1.9 \pm 0.01 \mathrm{nM}$ for RB49 with ET-1. As expected, no binding to CHO-WT cells was observed.

Rendomab A63 (RA63), a monoclonal antibody directed against human endothelin A receptor $\left(\mathrm{hET}_{\mathrm{A}}\right)$, established as RB1 and RB4 (Allard et al. 2013, Borrull et al. 2016), displayed binding to $\mathrm{hET}_{\mathrm{A}}$ that was very similar to the binding of RB49 to $\mathrm{hET}_{\mathrm{B}}$. Its binding to $\mathrm{hET}_{\mathrm{A}}$ was not modified by excess ET-1 (100 nM) (Fig. 1B) and, as expected, no binding to CHO-WT cells was observed. The calculated $K_{D}$ was $0.3 \pm 0.01 \mathrm{nM}$ in the presence or not of ET-1.

Rendomab $B 49$ has properties similar to those of rendomab B4, but with a different epitope

We have demonstrated that RB49 has the same recognition profile as RB4 for melanoma cell lines. RB49 also has the same recognition properties as RB4 regarding $\mathrm{hET}_{\mathrm{B}}$ expressed at the surface of $\mathrm{CHO}-\mathrm{ET}_{\mathrm{B}}$ cell.

The RB49 binding site on $\mathrm{hET}_{\mathrm{B}}$ was specified by a Pepscan approach, in which RB49 is hybridized with a membrane spotted with overlapping dodecapeptides, frame-shifted by one residue, and corresponding to the N-terminal domain and extracellular loops (E1, E2, E3) of human $\mathrm{ET}_{\mathrm{B}}$. There was only one region on the membrane revealed by RB49 (Fig. 2A). The alignment of the different peptides hybridized by RB49 allowed us to identify the peptide ${ }_{70}$ EVPKGDR $_{76}$, named ERB49-R1, which is located in the N-terminal domain of $\mathrm{hET}_{\mathrm{B}}$, as the epitope recognized by RB49 (Fig. 2B). 
A

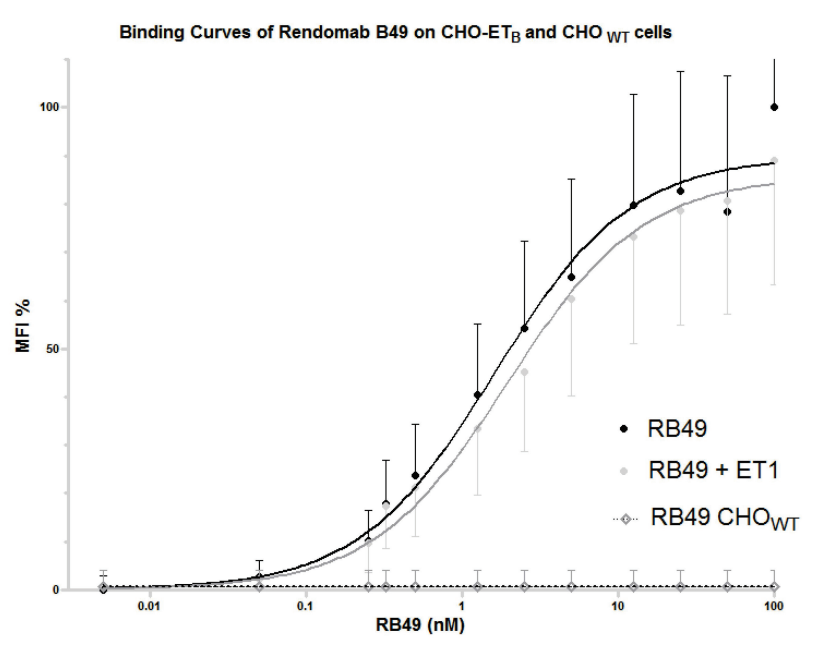

B

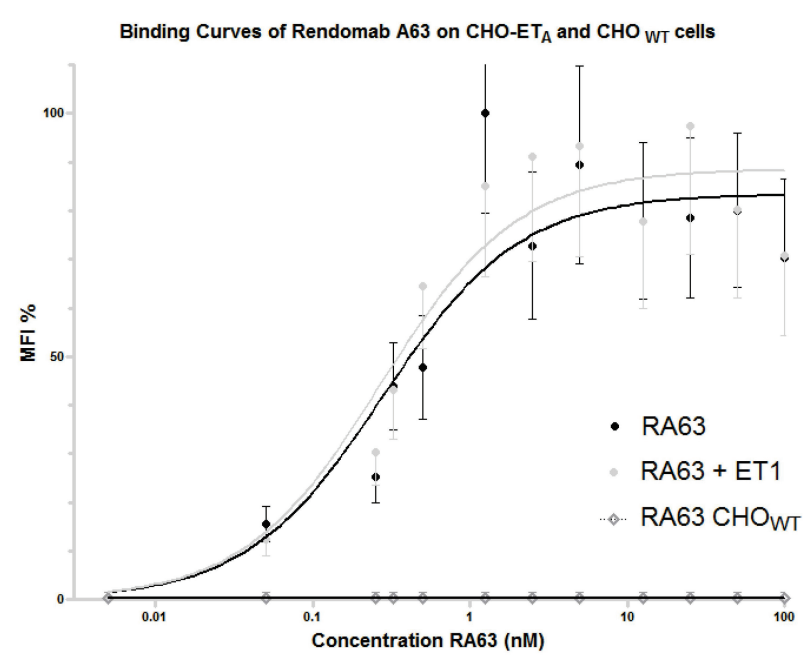

Fig. 1. Binding curves of $\mathrm{RB} 49$ (A) and RA63 (B) with $\mathrm{CHO}$ overexpressing human $\mathrm{ET}_{\mathrm{B}} \mathrm{CHO}-\mathrm{ET}_{\mathrm{B}}$ or $\mathrm{CHO}-\mathrm{WT}$ in the presence or not of excess ET-1 (100 nM). RB49 and RA63 binding was measured by flow cytometry (FACSCalibur) and yielded binding curves corresponding to mean fluorescence intensity (MFI) as a function of antibody concentration. The calculated $K_{D}$ was $1.6 \pm 0.01 \mathrm{nM}$ for RB49 and $1.9 \pm 0.01 \mathrm{nM}$ for RB49 with ET-1. For RA63, the calculated $K_{D}$ was $0.3 \pm 0.01 \mathrm{nM}$ in the presence or not of ET-1.

In Figure 2C, the location of the three epitopic peptides of RB1 is indicated in blue (Allard et al. 2013). We named these peptides ERB1-R1 (epitope rendomab B1-region 1, ${ }_{56}$ KGSNASLARSLA $\left._{67}\right)$, ERB1-R2 ( ${ }_{81}$ PPRTISP $\left._{87}\right)$ and ERB1-R3 (259PVQKTAFMQFYKTAKDWWL $\left.{ }_{277}\right)$. ERB1-R1 and ERB1-R2 are located in the N-terminal domain whereas ERB1-R3 is located in the extracellular loop 2 (ECL-2).
The location of the two epitopic peptides of RB4 is indicated in red in Figure 2C (Borrull et al. 2016). Following the same rule as for the peptide previously described, we named the peptides ERB4-R1 $\left({ }_{28}\right.$ ERGFPPDRATP $\left._{38}\right)$ and ERB4-R2 ( ${ }_{70}$ EVPKGDRT $\left._{77}\right)$.

Rendomab B49 and rendomab A63 are capable to bind to tumor cell lines

The RB49 binding curve for the UACC-257 cell line was obtained by flow cytometry (Fig. 3A). We deduced from it an apparent $K_{D}$ close to $20 \mathrm{nM}$. In parallel, we observed very high RB49 labeling of GSC (Fig. 3D), underscoring the capacity of this group I antibody to bind to $\mathrm{ET}_{\mathrm{B}}$ expressed on different human cancer cells. As $\mathrm{ET}_{\mathrm{A}}$ is not expressed by the human melanoma cell line, we immunolabeled GSC with RA63. The binding curve shown in Figure 3 (E) indicates an apparent $\mathrm{K}_{\mathrm{D}}$ close to $15 \pm 0.40 \mathrm{nM}$, and Figure $3(\mathrm{H})$ shows intense immunolabeling.

\section{In vivo imaging of brain tumors with rendomab A63}

After checking that RA63 binds to human GSC in vitro, we evaluated its capacity to detect brain tumors in vivo in a preclinical model consisting of a human GSC orthotopic xenograft in nude mice. We co-injected mice intraperitoneally with RA63 coupled with the fluorochrome AF680 (RA63-AF680) and the isotype control, the negative control, coupled with the fluorochrome AF750 (NC-AF750). Ten days later, to allow the complete blood circulation elimination of mAbs, we performed in vivo fluorescent imaging. The results are presented in Figure 4 . The mice were simultaneously imaged at $680 \mathrm{~nm}$ and $750 \mathrm{~nm}$ (Fig. 4A). As expected, for the control mouse with no GSC xenografts, no signal was detected in the isolated brain. In the xenograft mouse, in the conditions needed for RA63-AF680 fluorescence detection, we observed a strong fluorescent signal from the mouse skull; no signal was detected for NC-AF750. We also analyzed the brains (ex vivo imaging) of these mice (Fig. 4B). As expected, we confirmed the results obtained in vivo, which is to say, no detection with NC-AF750 in the xenografted mouse brain and, interestingly, a spread fluorescent signal was observed with RA63-AF680 in the same xenografted mouse brain. The fluorescent was present in ipsi-lateral and contra-lateral hemispheres and tumoral cells were detected by the RA63-AF680 antibody in the telencephalon, mesencephalon and metencephalon. 


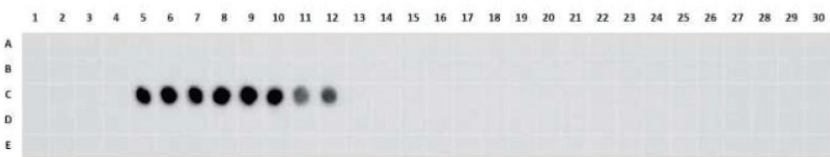

B

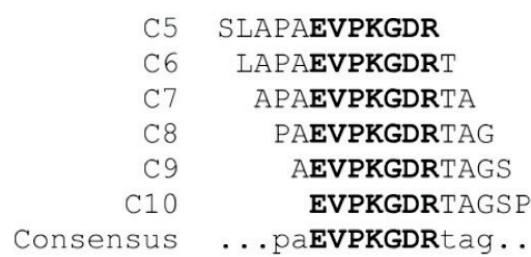

C

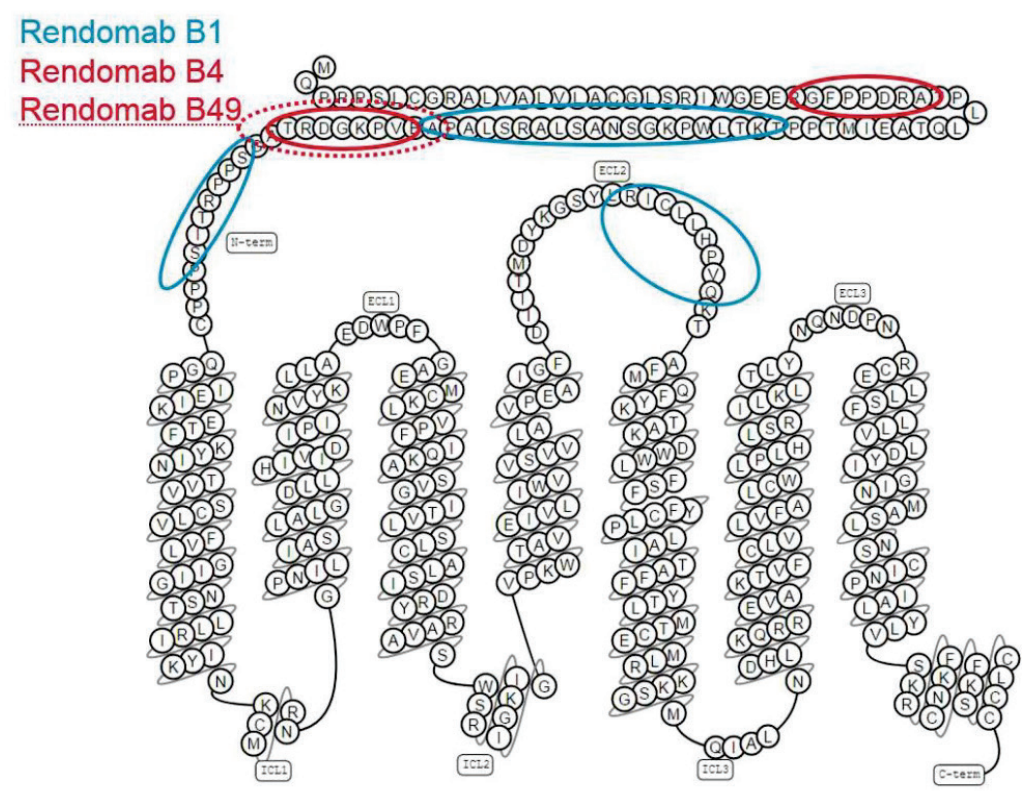

Fig. 2. A. Epitope mapping was investigated using a Pepscan membrane spotted with dodecapeptides (frameshifted by one amino acid) covering the entire human $\mathrm{ET}_{\mathrm{B}}$ extracellular regions. Interacting peptides were revealed using an alkaline phosphatase conjugated secondary antibody. B. Peptide sequences ( $\mathrm{C} 5$ to $\mathrm{C} 10$ ) were aligned to determine the epitope, amino acids in bold, recognized by Rendomab B49. C. Rendomab-B1 (blue) recognizes a discontinuous epitope on $\mathrm{hET}_{\mathrm{B}}$. Rendomab-B4 (red) recognizes two distinct peptides in the $\mathrm{N}$-terminal domain. Rendomab B49 (red dots) recognizes one peptide in the $\mathrm{N}$-terminal domain.

\section{Discussion}

We have previously noted differential binding of our antibodies, RB1 and RB4, to human melanoma cells (Allard et al. 2013, Borrull et al. 2016). Briefly, both antibodies bind with a high affinity and specificity to $\mathrm{hET}_{\mathrm{B}}$ expressed on $\mathrm{CHO}$ cells and, as expected, no

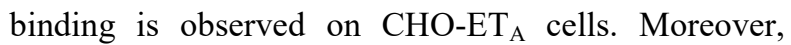
RB1 displays very low binding to UACC-257 melanoma cells overexpressing human $\mathrm{ET}_{\mathrm{B}}$, but we observe high binding to HUVEC. Conversely, RB4 binds with high affinity to $\mathrm{ET}_{\mathrm{B}}$ on UACC-257, but binds poorly to HUVEC and, of course, does not bind to $\mathrm{CHO}_{\mathrm{E}} \mathrm{ET}_{\mathrm{A}}$. We previously concluded that a human $\mathrm{ET}_{\mathrm{B}}$ tumor conformation is expressed at the surface of the melanoma cells. Here, for all $24 \mathrm{mAbs}$ we produced against $\mathrm{hET}_{\mathrm{B}}$, we evaluated their capacity to bind $\mathrm{ET}_{\mathrm{B}}$ expressed by different human melanoma cells (UACC-257; WM-266-4 and SLM8). Surprisingly, we observed a very heterogeneous antibody-dependent binding profile. We classified these profiles into six groups (I to VI, Table 1). The $9 \mathrm{mAbs}$ of group I, including RB4 and RB49, bound to the $\mathrm{hET}_{\mathrm{B}}$ expressed by all the cells screened. Conversely, the $5 \mathrm{mAbs}$ of group II, represented by RB1, only bound $\mathrm{CHO}-\mathrm{ET}_{\mathrm{B}}$. Most surprisingly, the mAbs of groups III, IV, V and VI displayed binding profiles as a function of the melanoma cell lines. They all bound $\mathrm{CHO}_{\mathrm{E}} \mathrm{ET}_{\mathrm{B}}$, because they were selected on the basis of this criterion, but, for example, the $2 \mathrm{mAbs}$ of group VI recognized only the SLM8 and the $3 \mathrm{mAbs}$ of group III recognized only two different melanoma cell lines (UACC-257 and WM-266-4, and not SLM8). We demonstrated that the binding of these mAbs is well mediated by $\mathrm{hET}_{\mathrm{B}}$, by observing a marked decrease (more than $80 \%$ of binding) after incubation of the cells with ET-1 $(100 \mathrm{nM})$ at $37^{\circ} \mathrm{C}$, leading to the internalization of $\mathrm{hET}_{\mathrm{B}}$ (data not shown). We have no clear explanation for these results. We hypothesize that $\mathrm{hET}_{\mathrm{B}}$ could have different cell-dependent conformations. 

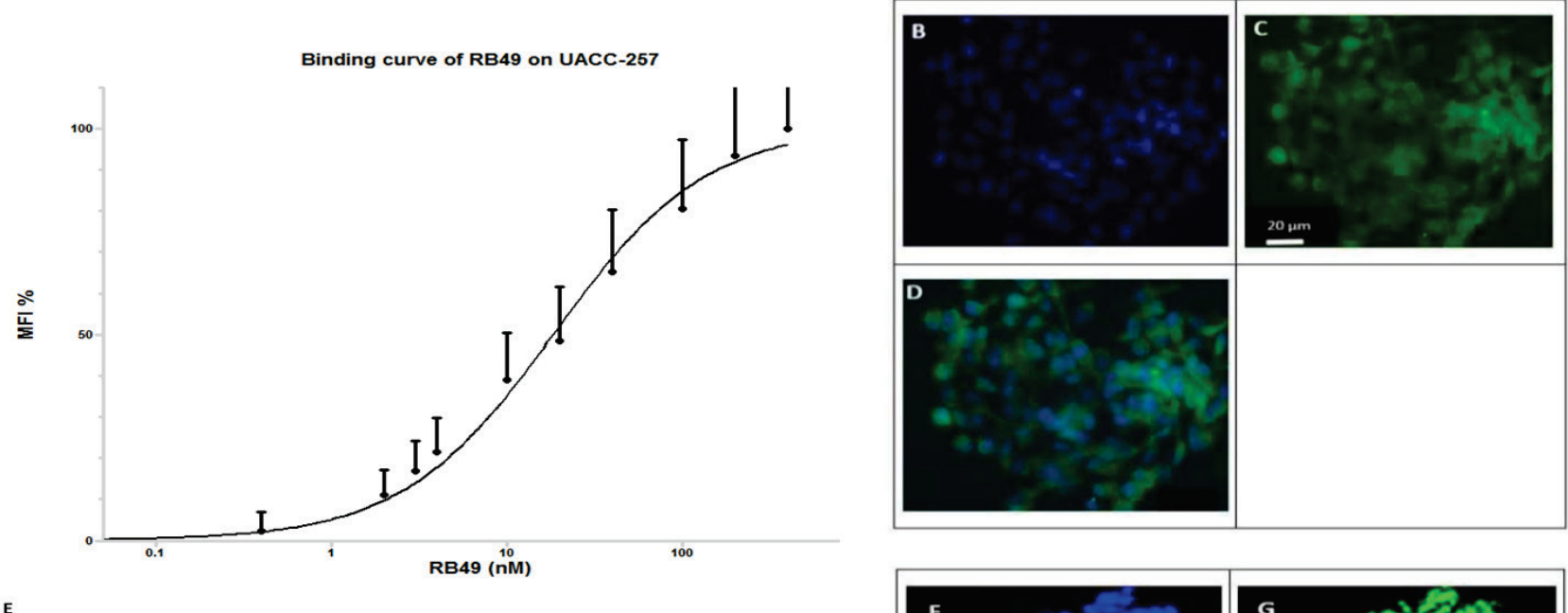

Binding curve of Rendomab A63 on GSC
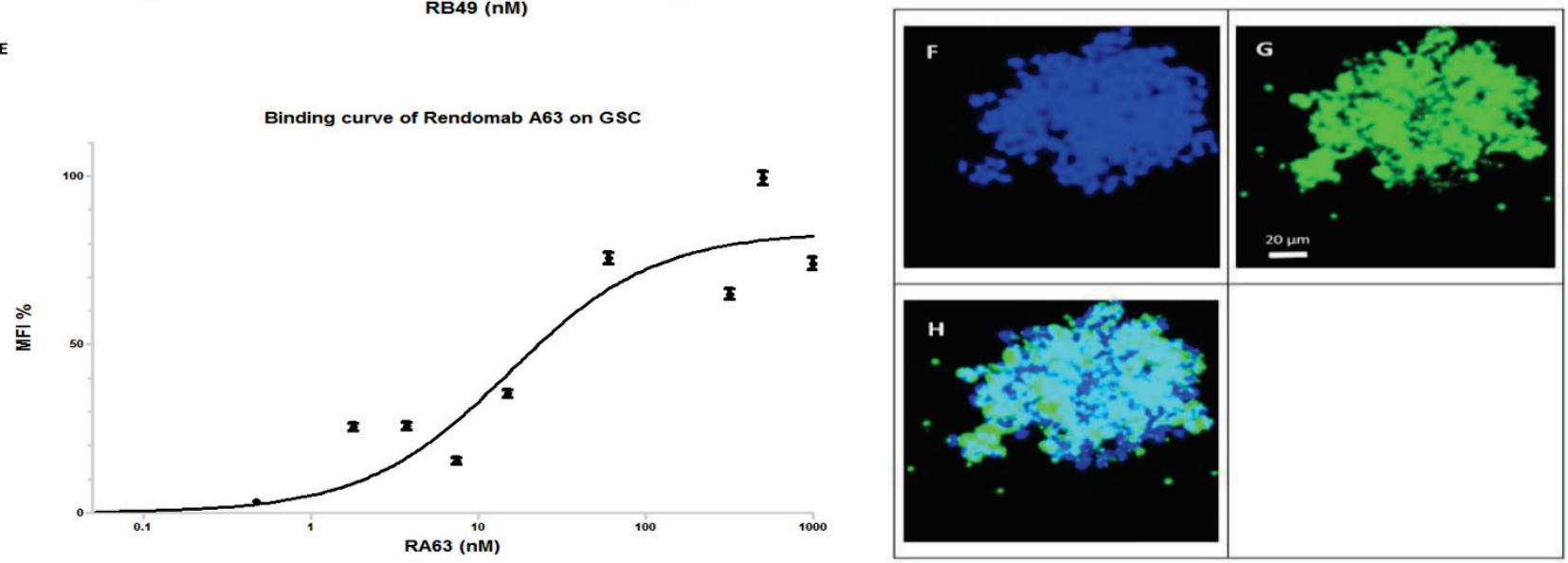

Fig. 3. Binding of RB49 and RA63 on tumor cells. A, the binding curve of RB49 with UACC-257 gives an apparent $K_{D}$ close to $18.6 \mathrm{nM}$. $\mathbf{E}$, the binding curve of RA63 with GSC gives an apparent $K_{D}$ close to $15.4 \mathrm{nM}$. Immunolabeling experiments on GSC. B, picture of blue staining of cell nuclei. C, second picture green cell labeling with RB49 revealed by a secondary antibody coupled with the AF488 fluorochrome. D, picture is the previous two merged. $\mathbf{F}$, picture of blue staining of cell nuclei. $\mathbf{G}$, second picture green cell labeling with RA63 revealed by a secondary antibody coupled with the AF488 fluorochrome. $\mathbf{H}$, picture is the previous two merged.
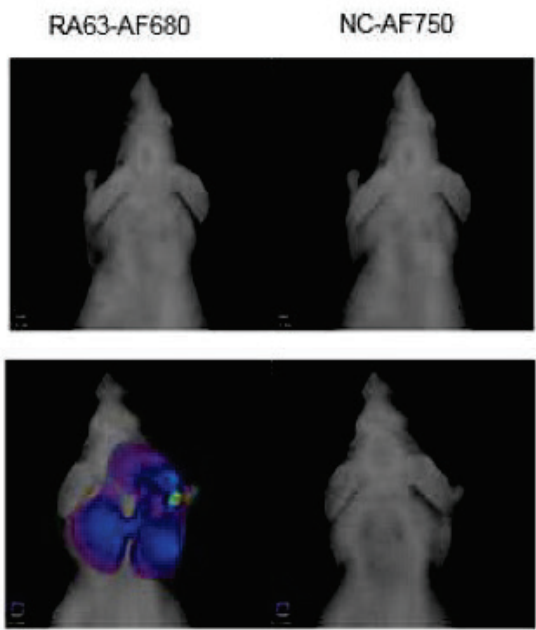

B
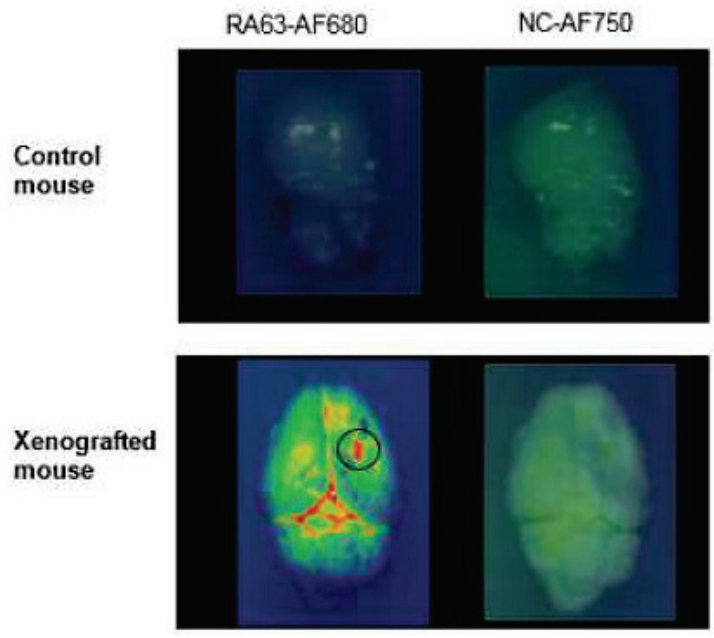

Fig. 4. A. In vivo fluorescent detection. Simultaneous fluorescence acquisition at $680 \mathrm{~nm}$ and $750 \mathrm{~nm}$ either on a control mouse or on a xenografted mouse. Both mice were previously co-injected intraperitoneally with RA63-AF680 and NC-AF750 (isotype negative control). B. Normal and xenografted brains were removed and then imaged as previously. Black circle indicates the GSC injection site. 
In particular, in dysfunctional cells like the melanoma cells studied here. G-protein-coupled receptors have already been described as allosteric molecules and their conformations could be modified by different ligands present in the extracellular, intracellular and membrane environments (Kenakin and Miller 2010). Recently, the structure of $\mathrm{hET}_{\mathrm{B}}$ in the presence or not of ET-1 and bosentan has been solved and shows allosteric modifications of the conformation of human $\mathrm{ET}_{\mathrm{B}}$ receptor (Shihoya 2016, Shihoya 2017). $\mathrm{ET}_{\mathrm{B}}$ conformational sensitivity to environmental ligands could explain the "specific cellular conformation" suggested by our mAb binding results.

We analyzed in more detail RB49, a group I $\mathrm{mAb}$, as RB4. RB49 yields a binding curve with CHO-ET $_{B}$ very similar to that previously observed with RB4. The apparent affinity calculated is $1.6 \mathrm{nM}$ and was not modified $(1.9 \mathrm{nM})$ in the presence of excess ET-1 $(100 \mathrm{nM})$. We determined, by epitope mapping, a single region preferentially recognized by this approach as the EVPKGDR peptide located in the N-terminal extremity of $\mathrm{ET}_{\mathrm{B}}$. This epitope is shared with $\mathrm{RB} 4$, which has another epitopic peptide, GFPPDRA, also located in the $\mathrm{N}$-terminal region. We could consider the RB49 epitope as the "minimum region" necessary and sufficient to target all $\mathrm{hET}_{\mathrm{B}}$ conformations exposed on different cell lines. Nevertheless, epitope mapping by the Pepscan approach, by displaying only linear peptides on a solid support, may not reflect the reality of the RB49-ET interaction. We can also note that the apparent $\mathrm{K}_{\mathrm{D}}$ of RB49 is lower with UACC-257 (close to $20 \mathrm{nM}$ ) than that observed with $\mathrm{CHO}_{\mathrm{B}} \mathrm{ET}_{\mathrm{B}}$, which supports the hypothesis of a modified $\mathrm{ET}_{\mathrm{B}}$ conformation at the surface of UACC- 257.

Recently, we also produced mAbs against human $\mathrm{ET}_{\mathrm{A}}$, in exactly the same way as for mAbs against $\mathrm{hET}_{\mathrm{B}}$. Rendomab A63 (RA63) displays properties similar to those of RB49: i) nanomolar $K_{D}(0.3 \mathrm{nM})$, ii) no binding modification, $\mathrm{K}_{\mathrm{D}}=0.3 \mathrm{nM}$ unchanged in presence of excess ET-1, iii) capacity to bind to $\mathrm{ET}_{\mathrm{A}}$ at the surface of human GSC with a lower $\mathrm{K}_{\mathrm{D}}(15 \mathrm{nM})$. Our study of the RA63 epitope is in progress. RA63 binds $\mathrm{ET}_{\mathrm{A}}$, which is expressed at the surface of GSC (Harland et al. 1998,
Sone et al. 2000, Bowman et al. 2017).

As RA63 targets GSC in vitro, we evaluated its capacity to detect tumor progression by in vivo fluorescence imaging in a preclinical model. We first demonstrated that RA63-AF680 and a negative isotypic control antibody (NC-AF750) generate no signal in a normal mouse with no tumor and also in its isolated brain. As shown in Figure 4, in an orthotopic xenograft mouse, in vivo fluorescent detection visualized an intense signal generated by RA63-AF680 at the mouse skull, whereas, in a simultaneous acquisition, no signal was detected with NC-AF750. After harvesting the mouse brain, we did the same simultaneous imaging and confirmed the previous observations, i.e. a diffuse fluorescent signal in the mouse brain with RA63-AF680 and no signal with NC-AF750. The imaging results suggest high infiltration of GSC through the xenografted mouse brain. It is important to note that at this stage of tumor propagation, 3 months post-graft, the mouse presents no symptoms of the disease. These observations made in the mouse model are very similar to those of tumor propagation observed in patients.

These preliminary results are promising for the development of antibody-drug conjugates with RB49 and RA63 for therapeutic applications in diseases where the endothelin axis and its ET-1 receptors are dysfunctional and overexpressed. Nevertheless, particular attention should be accorded to the expression of $\mathrm{ET}_{\mathrm{A}}$ or $\mathrm{ET}_{\mathrm{B}}$ or both as a function of the tumor microenvironment and its development. In addition to the therapeutic approach, an in vivo diagnostic tool to classify patients is essential in order to deliver the appropriate antibody-drug conjugate and so optimize clinical benefit for the patient.

\section{Conflict of Interest}

There is no conflict of interest.

\section{Acknowledgements}

We thank Patricia Lamourette, Karine Moreau and Marc Plaisance for their expert assistance in monoclonal antibody production. This work was supported by grants from the Commissariat à l'Energie Atomique et aux Energies Alternatives (CEA, France).

\section{References}

ALLARD B, WIJKHUISEN A, BORRULL A, DESHAYES F, PRIAM F, LAMOURETTE P, DUCANCEL F, BOQUET D, COURAUD JY: Generation and characterization of rendomab-B1, a monoclonal antibody displaying potent and specific antagonism of the human endothelin B receptor. MAbs 5: 56-69, 2013. 
BARTON M, YANAGISAWA M: Endothelin: 20 years from discovery to therapy. Can J Physiol Pharmacol 86: 485-498, 2008.

BORRULL A, ALLARD B, WIJKHUISEN A, HERBET A, LAMOURETTE P, BIROUK W, LEIBER D, TANFIN Z, DUCANCEL F, BOQUET D, COURAUD J-Y, ROBIN P: Rendomab B4, a monoclonal antibody that discriminates the human endothelin $\mathrm{B}$ receptor of melanoma cells and inhibits their migration. MAbs $\mathbf{8}$ : 1371-1385, 2016.

BOWMAN RL, WANG Q, CARRO A, VERHAAK RGW, SQUATRITO M: GlioVis data portal for visualization and analysis of brain tumor expression datasets. Neuro Oncol 19: 139-141, 2017.

CLOZEL M, BREU V, BURRI K, CASSAL JM, FISCHLI W, GRAY GA, HIRTH G, MÜLLER M, NEIDHART W, RAMUZ H: Pathophysiological role of endothelin revealed by the first orally active endothelin receptor antagonist. Nature 365: 759-761, 1993.

DAVENPORT AP, HYNDMAN KA, DHAUN N, SOUTHAN C, KOHAN DE, POLLOCK JS, POLLOCK DM, WEBB DJ, MAGUIRE JJ: Endothelin. Pharmacol Rev 68: 357-418, 2016.

EGIDO J, ROJAS-RIVERA J, MAS S, RUIZ-ORTEGA M, SANZ AB, PARRA EG, GOMEZ-GUERRERO C: Atrasentan for the treatment of diabetic nephropathy. Expert Opin Investig Drugs 26: 741-750, 2017.

GUICHET PO, GUELFI S, TEIGELL M, HOPPE L, BAKALARA N, BAUCHET L, DUFFAU H, LAMSZUS K, ROTHHUT B, HUGNOT JP: Notch1 stimulation induces a vascularization switch with pericyte-like cell differentiation of glioblastoma stem cells. Stem Cells 33: 21-34, 2014.

HARLAND SP, KUC RE, PICKARD JD, DAVENPORT AP: Expression of endothelin(A) receptors in human gliomas and meningiomas, with high affinity for the selective antagonist PD156707. Neurosurgery 43: 890-898, 1998.

KENAKIN T, MILLER LJ: Seven transmembrane receptors as shapeshifting proteins: the impact of allosteric modulation and functional selectivity on new drug discovery. Pharmacol Rev 62: 265-304, 2010.

OPGENORTH TJ, ADLER AL, CALZADILLA SV, CHIOU WJ, DAYTON BD, DIXON DB, GEHRKE LJ, HERNANDEZ L, MAGNUSON SR, MARSH KC, NOVOSAD EI, VON GELDERN TW, WESSALE JL, WINN M, WU-WONG JR: Pharmacological characterization of A-127722: an orally active and highly potent ETA-selective receptor antagonist. J Pharmacol Exp Ther 276: 473-481, 1996.

ROSANÒ L, SPINELLA F, BAGNATO A: Endothelin 1 in cancer: biological implications and therapeutic opportunities. Nat Rev Cancer 13: 637-651, 2013.

SONE M, TAKAHASHI K, TOTSUNE K, MURAKAMI O, ARIHARA Z, SATOH F, MOURI T, SHIBAHARA S: Expression of endothelin-1 and endothelin receptors in cultured human glioblastoma cells. $J$ Cardiovasc Pharmacol 36 (Suppl 1): S390-S392, 2000. 